\title{
ПОДОЛАННЯ АНТИНОМІї ДЕТЕРМІНІЗМУ І СВОБОДИ В КОНЦЕПЦІЇ ГАБІТУСА П. БУРДЬЄ
}

\section{Т.В. Кушерець}

Проблема суб'єкта і, відповідно, суб'єкта історії була і залишається однією з провідних тем філософського дискурсу. Проте останнім часом у рамках кількох філософських напрямків (насамперед це стосується структуралізму, постструктуралізму та постмодернізму) ставиться питання про «кінець суб'єкта». Так, К. Леві-Строс заявив про «смерть людини», яка є лише засобом, за допомогою якого реалізуються та функціонують різноманітні структури. Р. Барт заговорив про «смерть автора», якщо розуміти автора як того, хто визначає смисл тексту. М. Фуко оголосив модерністську концепцію суб'єкта чимось, що можна стерти. «Як би не уявляли собі так званий постмодернізм у майбутньому, він буде сприйматися як епоха, яка вважала за можливе розпрощатися з поняттям суб'єкт» [4, с. 24].

П.Рікьор, погоджуючись з тим, що філософії суб'єкта загрожує знищення, стверджує, що ця філософія завжди підлягала спростуванню. «Конкретної філософії суб'єкта насправді ніколи і не було; скоріше існували лише змінювані один одним стилі рефлексії, що походили із діяльності по перевизначенню, яке породжувалося самим усуненням» [5, c. 362]. Тому, на думку мислителя, подальший розвиток філософії суб'єкта повинен здійснюватися не шляхом підтримки та збереження власної ідентичності, відбиваючи атаки противника, а через «вступ у шлюбний союз з тим, що вона більше за все заперечує» [5, с. 363].

Переосмисленню на сьогодні підлягає традиційне уявлення про суб'єкта як про раціональну істоту, що визначає та контролює ситуацію свого буття і здатна продукувати нові соціальні форми свого існування. Тому оновлення змісту поняття суб'єкта і, відповідно, суб'єкта

Актуальні проблеми духовності: зб. наук. праць / Ред.: Я.В. Шрамко

Вип. 10. - Кривий Ріг, 2009, 117-126 
історії пов'язане, по-перше, з виявленням інших, окрім Cogito, модусів людського існування, та, по-друге, із розкриттям зворотнього формуючого впливу соціальної системи на творчий потенціал людини. Стосовно першого, то цей аспект оновлення змісту поняття історичного суб'єкта був нами розглянутий раніше ${ }^{1}$. Стосовно другого, то, на наш погляд, саме такий шлях реконструкції змісту поняття суб'єкта історії обрав французький мислитель П.Бурдьє. Завдання данної статті полягає у виявленні того, наскільки реалізованим був цей задум у його концепції габітуса та наскільки плідною $\epsilon$ вона у плані подолання антиномії детермінізму і свободи в людській історії.

Перевизначення змісту поняття суб'єкта історії П. Бурдьє здійснював відштовхуючись від теоретичних надбань феноменології та структуралізму. Особливо плідними для подальшого аналізу виявилися два висновки, зроблені М. Мерло-Понті. По-перше, це стосується уявлень про узагальнену екзистенцію як основу для реалізації людиною себе як суб'єкта історії. По-друге, висновок про те, що свідомість людини завжди перебуває в залежності від «вказуючої» спонтанності її тіла 3 усіма його здобутими здібностями та наявним у неї словниковим запасом. Феноменологія відкрила світ значень, а значить світ мови, вперше тематизуючи інтенціональну та «означуючу» діяльність втіленого, сприймаючого, діючого та розмовляючого суб'єкта.

Подальше завдання феноменології, на думку П. Рікьора, полягало в тому, щоб показати, як «минуле» мови живе у мові теперішній, яким чином мовлення $\epsilon$ відродженням певних лінгвістичних значень, котрі надходять із старого арсеналу, що належить іншим людям, і відкладаються, «випадають в осад», стають наявним надбанням, за допомогою якого людина тепер може словесно заповнити ту порожнечу, якою є їі бажання означувати, коли вона починає говорити. Мерло-Понті ототожнив мову з «жестом», що приводить в рух уміння щось робити, тобто набуту здатність. Йому не вдалося прийняти до уваги те, як трактують мову структурні лінгвісти. «Той факт, що поняття про мову як автономну систему не приймається до уваги, важким тягарем тисне на таку феноменологію мовлення» [5, с. 383].

3 іншого боку, феноменологія розмовляючого, конкретного суб'єкта тяжіє до питань, які оминаються структуралізмом. Яким чином автономна система знаків, яка розглядається без розмовляючого су-

\footnotetext{
${ }^{1}$ Див.: Кушерещв Т.В. Покоління як суб'єкт історії в філософії Х. Ортеги-і-Гасета // Сіверянський літопис. - 2008. - № 3. - С. 111-116; Кушерецъ Т.В. Людська присутність як первинний суб'єкт історії у філософії М. Хайдеггера // Актуальні проблеми духовності. - Вип. 9. - Кривий Ріг, 2008. - С. 134-142.
} 
б’єкта, діє, досягає своєї рівноваги і завжди готова до використання та існування в історії? Чи може ця система існувати інакше, ніж в акті мовлення? «Чи є мова чимось більшим, ніж потенційна система, що ніколи не переходить в акт, сповнений прихованих змін, відкритий суб'єктивній та інтерсуб'єктивній історії?»[5, с. 384]. Участь системи в процесі «випадання в осад» можна визначити за допомогою поняття габітус, над змістом якого розмірковував П. Бурдьє.

Французький теоретик не вміщується в рамки якогось напрямку чи школи, він прагне інтегрувати різні концептуальні ідеї для вирішення на новому рівні традиційних для філософії проблем свободи і необхідності, свідомого та несвідомого, людини і суспільства. Коли він сам визначає напрямок свого теоретизування, то називає його конструктивістським структуралізмом або структуралістським конструктивізмом, вживаючи при цьому слово «структуралізм» у значенні, яке сильно відрізняється від того, яке йому надає соссюрівська або леві-стросівська традиція. «За допомогою структуралізму, - пише Бурдьє, - я хочу сказати, що в самому соціальному світі, а не тільки в символіці, мові, міфах і т. п. існують об'єктивні структури, незалежні від свідомості та волі агентів, здатні направляти або подавляти їхні практики або уявлення. За допомогою конструктивізму я хочу показати, що існує соціальний генезис, з одного боку, схем сприйняття, мислення і дії, котрі є складовими частинами того, що я називаю габітусом, а з іншого боку, - i соціальних структур i, зокрема, того, що я називаю полями або групами, і що зазвичай називають соціальними класами» [2, с. 181-182].

Бурдьє ставить перед собою завдання довести фальшивість як об'єктивістських так і суб'єктивістських концепцій, вказуючи на безпідставність ігнорування однієї з них. 3 одного боку, стверджує він, об'єктивні структури, що конструюються в рамках об'єктивізму, відсторонюючись від суб'єктивних уявлень агентів, лежать в основі суб'єктивних уявлень і містять структурні примуси, які впливають на взаємодію. Але, з іншого боку, ці уявлення повинні бути засвоєними, якщо хочуть, щоб з ними рахувались, зокрема в індивідуальній або колективній повсякденній боротьбі, спрямованій на трансформацію або збереження об'єктивних структур. 3 цього видно, що обидва підходи об'єктивістський та суб'єктивістський є взаємопов'язаними.

Хоча Бурдьє працює з тією ж самою проблематикою, яку свого часу розвивали представники феноменологічної школи, а саме: з взаємопроникненням суб'єктивного та об'єктивного «світів», він не сприймає традиційної термінології, якою користувалися представники згадано- 
го напрямку. Для кращого осягнення зв'язку, діалектичної залежності між об'єктивним і суб'єктивним, він розробив і застосував нові поняття «габітус» та «поле», де перше стосується того, що міститься у свідомості діячів, а друге - того, що залишається поза їхньою свідомістю.

Мислитель повністю переосмислив старе аристотелівсько-томістське поняття габітус з метою уникнення вибору між структуралізмом без суб'єкта та філософією суб'єкта. Він писав, що деякі феноменологи, зокрема Гуссерль, Мерло-Понті, Хайдеггер вказали йому на шлях ні інтелектуалістичний, ні механістичний - до аналізу між агентом та світом. Поняття габітусу народилося із прагнення показати, що поряд із категоричною експліцитною нормою або раціональним розрахунком $\epsilon$ інші спонукальні принципи практики. «Габітус, як система наперед заданих схильностей до практики є об'єктивним фундаментом упорядкованої поведінки, а відповідно, упорядкованості поведінки» [2, с. 119].

Габітус - це ментальні або пізнавальні структури, за допомогою яких люди живуть у соціальному світі, спрямовуються у своїх діях. Це сукупність схем, шаблонів, за допомогою яких люди сприймають, розуміють і оцінюють світ. Він дозволяє індивідові спонтанно орієнтуватися у соціальному просторі і реагувати більш чи менш адекватно на події та ситуації. Формування габітуса $є$ результатом тривалого зайняття індивідом певної соціальної позиції, тому він залежить від сутнісних рис цієї позиції. Габітус $€$ продуктом характерологічних структур певного класу, умов його існування. Інтеріоризація життєвого досвіду у певному оточенні, часто залишаючись неусвідомленою, призводить до формування готовності і здатності індивіда реагувати, говорити, відчувати, думати певним - тим, а не іншим - способом.

Люди, що займають в одному соціумі різні позиції, але мають схожі положення, мають також подібні габітуси, близьке, але не уніфіковане, сприйняття цього світу. Проте людина впродовж життя може змінювати соціальні середовища свого існування, засвоюючи різні способи поведінки і мислення. Відповідно габітус кожного $є$ неповторним. Тому Бурдьє називає габітус інкорпорованою i, відповідно, індивідуалізованою соціальністю. «Габітус можна визначити як певну диспозицію дій, способу відчуття, осмислення і оцінювання суб'єктом соціального світу, певну сукупність внутрішніх установок, яких набуває людина у процесі практики, настанов, що в ній укорінились, що результують засвоєні знання і досвід певного місця перебування у соціальному просторі» [6, с. 219].

Габітус формується середовищем, колективною історією спільнот, і при виявленні в індивідуальних діях, він все-таки демонструє особли- 
вості колективного досвіду певної спільноти. Деякі соціальні середовища активніше, ніж інші, формують габітус. Особливо слід відзначити соціальні умови, в яких проходить дитинство індивіда, бо саме їхній вплив залишається найбільш помітним і утворює основу габітуса. Однак у всіх людей різні здібності і різні можливості на практиці можуть мати користь із досвіду, отриманого у роки дитинства. Тому, коли індивід зустрічається зі способом дій і системою поглядів, сформованими іншими соціальними середовищами, він різним чином переплітає їх, створюючи частину нового габітусу. Сам Бурдьє вважає, що його внесок у розвиток науки пов'язаний з його габітусом, з якого він зумів отримати користь. Французький соціолог пройшов шлях від селянського сина до вченого зі світовим ім'ям і при цьому «сприйняв багато таких можливостей, котрі більшість людей втрачали» [2, с. 45].

Ще одна суттєва характеристика габітуса полягає в тому, що він знаходиться нижче рівня свідомості та мови, виходить за межі інтроспективного аналізу та непідконтрольний індивідуальній волі. Люди не можуть осягнути, як він оперує. Він проявляється в індивідуальній практиці, в манері поводитися. «Поведінка, породжена габітусом, не має красивої упорядкованості: габітус виступає у парі з розпливчастістю і невизначеністю. Будучи породжуючою спонтанністю, котра утверджується в імпровізованій конфронтації з безперервно поновлюваними ситуаціями, габітус підпорядковується практичній логіці-логіці невизначеності, „чогось ніби...",- котра визначає звичне ставлення до світу» $[2$, с. 120]. Бурдьє порівнюе габітус із «почуттям гри», яке властиве людям того чи іншого соціального кола, яке дає їм змогу адекватно орієнтуватися у безлічі конкретних життєвих ситуацій, де далеко не все передбачене правилами, а іноді ці правила створюються у процесі гри.

Така недетермінованість, відкритість, невизначеність $€$ тим, що робить неможливим повністю покладатися на габітус у критичних ситуаціях. Французький мислитель вважає, що чим більш загрозливішою є ситуація, тим більше прагнуть кодифікувати (формалізувати і дотримуватися формальностей) практику. А якщо ситуація потенційно погрожує насиллям, то тим більше поведінка, яка покладається на вільну імпровізацію габітусу, буде поступатися поведінці, яка регламентується різними соціальними нормами, правилами. Тому «габітус $\epsilon$ основою вигадування, але у певних межах» [2, с. 125].

Габітус, на думку Бурдьє, - це продукт історії, який продукує індивідуальні та колективні практики - знову історію - у відповідності зі схемами, що породжуються самою історією. Він обумовлює активну 
присутність минулого досвіду та гарантує «правильність» практик та їхню постійність у часі більш надійно, ніж усі формальні правила та експліцитні норми. Така система схильностей є тим принципом відтворюваності та регулярності, який відмічається у соціальних практиках послідовниками об'єктивізму, але не знаходить у них пояснення, а також принцип регульованих перетворень, який не може бути поясненим ні зовнішнім детермінізмом механістичного соціологізму, ні суто внутрішньою, але такою ж несподіваною детермінацією спонтанного суб'єктивізму.

За допомогою габітуса структура, продуктом якої він є, керує практикою, однак не в дусі механістичного детермінізму, а в рамках примусів та меж, наперед накладених на її винаходи. Цю нескінченну, однак строго визначену породжуючу здатність важко зрозуміти, залишаючись у полоні традиційних для філософії антиномій детермінізму та свободи, обумовленості середовищем та винахідливості, свідомого та несвідомого, або індивіда та суспільства. Саме на їх подолання і спрямована концепція габітуса. «Оскільки habitus - це безкінечна здатність для продукування думок, сприйняття, вираження та дій, - межі якої задані історичними та соціальними умовами його виробництва, то і обумовлена та умовна свобода, яку він представляє, так само далека від створення непередбачуваного нового, так і від простого механічного відтворення первісних умов» [1, с. 108].

Бурдьє стверджує, що саме габітус дає діям людей їхню відносну незалежність від будь-яких зовнішніх детермінант. Ця автономія є автономією минулого, котре функціонуючи як акумульований капітал, виробляє історію на основі історії і у такий спосіб гарантує постійні зміни, які утворюють для індивіда його світ у зовнішньому світі. «Агенти ніколи не бувають вільними, але ніколи ілюзія свободи (або відсутність примусу) не буває настільки повною, як у випадку, коли вони діють у відповідності зі схемами свого габітуса, тобто об'єктивних структур, продуктом яких $є$ сам габітус: у цьому випадку агенти відчувають примус не більше, ніж вагу повітря» (цит. за: [7, с. 60-70]).

На думку французького мислителя, тоді - і тільки тоді - коли габітус вписується у структуру і є частиною самої історії, точніше історії об'єктивованої в габітусі та структурах, породжувані ним практики є взаємозрозумілими та безпосередньо адаптованими до структур. При цьому вони дані об'єктивно і наділені об'єктивним значенням, тобто одночасно одиничним і систематичним, що виходить за межі суб'єктивних інтенцій і свідомих індивідуальних або колективних проектів. Одним із фундаментальних наслідків гармонії практичного почуття 
та об'єктивного значення є продукування світу здорового глузду. Гомогенність габітусу, котра спостерігається в межах деякого класу умов існування та соціального середовища, обумовлює те, що практики та дії є безпосередньо усвідомленими та передбачуваними і у такий спосіб сприймаються як само собою зрозумілі.

Об'єктивна гомогенізація групового або класового габітуса, що випливає із гомогенності умов існування, дозволяє практикам бути об'єктивно гармонійними без усякої калькуляції або свідомого співвіднесення 3 нормами та явної координації. «Габітус-це саме такий іманентний закон, вписаний у тіла єдиною історією, що є основою не тільки для координації практик, але також і для практик координації [1, с. 116]. Поправки та регулювання, які свідомо вносять самі агенти, передбачають володіння певним спільним кодом. Спроби мобілізації колективу не можуть увінчатися успіхом без мінімального співпадіння габітусів мобілізуючих агентів (пророків, лідерів) та схильностей тих, хто впізнає себе в їхніх практиках та промовах, і поза групоутворенням, що виникає в результаті спонтанної відповідності схильностей. «Очевидно, що кожне зусилля мобілізації, спрямоване на організацію колективної дії, повинне враховувати діалектику схильностей та випадковостей, котрі закладені у кожному агентові незалежно від того чи мобілізує він, чи мобілізують його» [1, с. 117].

Тенденція підтримки груп завдяки тому, що вони утворюються із індивідів зі стійкими схильностями, які можуть «пережити» економічні та соціальні умови, в яких вони були сформовані, може слугувати джерелом як адаптації, так і відсутності адаптації, і бунту, і підкорення. Бурдьє ставить завдання розглянути інші можливі форми відношень між схильностями та умовами, щоб пересвідчитись, що наперед задана пристосованість габітуса до певних умов є лише «можливим окремим випадком», i, у такий спосіб, уникнути несвідомої універсалізації моделі абсолютного відтворення, котра спрацьовує лише тоді, коли умови виробництва габітуса і умови його функціонування ідентичні або гомотетичні.

Французький мислитель не оминув проблему впливу владних відносин на реалізацію людиною своїх життєвих перспектив. Він стверджує, що лише у вигаданому досвіді, наприклад, у народній казці, який нейтралізує почуття соціальної реальності, соціальний світ перетворюєься на всесвіт можливостей, що є однаково здійсненними для кожного суб'єкта. Індивіди формують свої очікування у відповідності з конкретними індикаторами досяжного та недосяжного, того, що «для нас» $\mathrm{i}$ «не для нас», - поділом таким же фундаментальним, як i 
глибоко засвоєним. Переважаючі права на майбутнє, визначені законом та монопольним правом на визначення можливості, $\epsilon$ всього лише експліцитно гарантованою формою усієї системи відповідних шансів, через які існуючі відносини влади проектують себе в майбутнє, звідки вони керують теперішніми схильностями, особливо тими, котрі спрямовані на майбутнє. Фактично існуюче практичне ставлення агента до майбутнього, яке керує його теперішньою практикою, визначається відношенням між габітусом з його часовими структурами і схильностями стосовно майбутнього, сконструйованими у певному всесвіті ймовірностей, з одного боку, і певним станом шансів, об'єктивно запропонованих агенту соціальним світом, -3 іншого. «Ставлення до того, що можливо, $є$ ставленням до влади. Уявлення про ймовірне майбутнє складається впродовж усього життя, в результаті взаємодії зі світом, структурованим у відповідності з категоріями можливого (для нас) i неможливого (для нас), існуючого завідомо для інших та реального для себе. Габітус-це принцип вибіркового сприйняття індикаторів, спрямованих скоріше на підтвердження та посилення габітуса, ніж на його трансформацію, це матриця, що генерує реакції, наперед пристосовані до усіх об'єктивних умов, ідентичних або гомологічних з (минулими) умовами виробництва габітуса» $[1$, с. 125-126]. Він пристосовує себе до ймовірного майбутнього, яке він передбачає та допомагає здійснити, оскільки «читає» його безпосередньо у теперішньому передбачуваному світі, єдиному, який він може знати.

Бурдьє критикує різноманітні версії теологічної філософії історії, яка прагне до того, щоб слова, що позначають інститути та колективи - Держава, Буржуазія, Церква, Школа, Сім'я, Правосуддя тощо конституювались у історичні суб'єкти, що здатні формулювати та реалізовувати власні цілі. У якості механічного виконавця історичної доцільності така філософія може використовувати алегоричні образи домінування, наприклад, Апарат, та «на противагу йому такі містичні персоніфікації як Робітничий клас, Пролетаріат, Трудящі, або навіть Боротьба - уособлення Соціального руху та його месницького гніву» [3, с.266]. Така філософія історії шукає сутність за видимістю, структуру по той бік історії та усього того, що її власне визначає. «Зводити агентів до ролі виконавців, жертв або співучасників політики, зафіксованій у Сутності апаратів, це означає обгрунтовувати виведення існування із сутності» [3, с. 267]. Бурдьє критикує авторів телеологічних ілюзій, які, на його думку, $є$ різновидами тієї форми ретроспективного аналізу, який дозволяє приписувати наміри та умисли індивідуальним агентам та персоналізованим колективам. 
Філософія історії, на думку мислителя, виявилася у полоні згубних альтернатив, які базуються на протистоянні між індивідуальним та соціальним (що ототожнюється з колективним), між «великими людьми» та колективними силами, одиничними волями та формами структурного детермінізму, звідки з'являється відмінність між подієвим та довготривалим у описах історії. Вихід із теоретичної кризи Бурдьє вбачає у тому, щоб «звернути увагу на те, що будь-яке історичне діяння повертає нас обличчям до двох станів історії (або соціального): істоpiï у її об'єктивному стані, тобто історії, що упродовж тривалого часу акумулювалась у речах, машинах, спорудах, пам'ятниках, книгах, теоріях, звичаях, праві тощо, та історії в їі інкорпорованому стані, що стала габітусом» [3, с. 272].

Об'єктивований соціальний світ актуалізується людьми через габітус, в якому проявляється історичний досвід. «Інституціоналізована, об'єктивована історія стає історичним діянням, тобто історією, що приводиться до дій та діючою, якщо тільки до її здійснення прилучаються агенти, котрих до цього підготовлює їхня історія, та які в силу своїх попередніх „капіталовкладень“ схильні до того, щоб цікавитись їхнім функціонуванням та мають здібності, необхідні для того, щоб змусити їх функціонувати» [3, с. 273].

Ставлення до історії в їі об'єктивованому стані не є ставленням аналогічним механічній доконечності, що часто встановлюється між «середовищем» та свідомістю. Бурдьє називає таке ставлення своєрідною онтологічною співучастю. Коли одна і та ж сама історія наповнює і габітус, і середовище існування, диспозицію і позицію, короля і його двір, власника підприємства та його підприємство, єпіскопа та його єпархію, історія деяким чином повідомлюється сама собі, самовідображується. «Історія-,,суб'єкт“ розкривається сама собі в історії„об'єкті“: вона впізнає себе в „допредикативних“, „пасивних синтезах“, в структурах, що структурувалися до будь-якої операції структурування та будь-якого лінгвістичного вираження» [3, с. 273-274].

Принцип «вічного рушія історії» Бурдьє вбачає не у якомусь первинному непорушному двигуні, а у боротьбі, яка виникає під впливом структур, що утворюють поле, та відтворює ці структури, а разом 3 ними й ієрархічні відносини. Він полягає у діях протидіючих агентів, у яких, якщо вони тільки не виходять із гри і не йдуть у небуття, не залишається іншого вибору, як боротися, щоб зберегти або покращити свої позициї в полі, тобто, щоб зберегти або збільшити специфічний капітал, котрий народжується тільки в полі, сприяючи тим самим збереженню тиску на інших, примусів, що породжуються конкуренцією, 
які часто переживаються як нестерпні [3, с. 276].

Людська діяльність носить характер боротьби між історією об'єктивованою та історією інкорпорованою, між габітусами, створюваними для одних посад, і посадами, створюваними для інших габітусів. Це спостерігається, як доводить Бурдьє, і в революційних та постреволюційних ситуаціях, і в ситуації соціального порядку, де завжди мають місце зони нестійкої соціальної структури. «Історія твориться у цій боротьбі, у цій прихованій битві, в ході якої посади більш або менш повно формують тих, хто їх займає та прагне ними заволодіти, коли агенти більш або менш повно змінюють посади, переробляючи їх за своїми мірками» [3, с. 294-295].

Французький мислитель однаково зосереджується як на дослідженні габітуса, так і на дослідженні соціального світу, з його диференціацією, стратифікацією та владними відносинами, оскільки, на його думку, без цього неможливо уявити собі справжню свободу. «Соціальний світ у значній мірі $€$ тим, чим його роблять у кожний момент його агенти; але зруйнувати та переробити зроблене можна лише на основі реального знання про те, чим $є$ соціальний світ, і який вплив агенти здійснюють на нього в залежності від займаної ними позиції» [3, c. 77]. Саме примноженню такого знання присвячені життя і творчість П. Бурдьє.

\section{1 Бібліографія}

[1] Бурдъе П. Практический смысл. - СПб., 2001.

[2] Бурдъе П. Начала. - M.: Socio-Logos, 1994.

[3] Бурдъе П. Социология политики.-M.: Socio-Logos, 1993.

[4] Кимелев Ю.А. «Субъект» и «субъективность» в современной западной социальной философии. - М., 2006.

[5] Рикер П. Конфликт интерпретаций. Очерки о герменевтике. - М., 1995.

[6] Ручка А.О., Танчер В.В. Курс історії теоретичної соціології. - К., 1995.

[7] Шматко Н.А. Габитус в структуре социологической теории // Журнал социологии и социологической антропологии. 1998. T. 1. 一№ 2. - C. 60-70. 